\title{
PENGARUH MODEL PEMBELAJARAN DIRECTED READING THINKING ACTIVITY (DRTA) TERHADAP KETERAMPILAN MEMBACA CEPAT SISWA
}

\author{
Ni Wayan Ani Astari \\ Jurusan Pendidikan Guru Sekolah Dasar, Universitas Pendidikan Ganesha \\ ni.wayan.ani.astari@undiksha.co.id
}

\begin{abstract}
Abstrak
Penelitian ini bertujuan untuk mengetahui pengaruh model pembelajaran Directed Reading Thinking Activity (DRTA) terhadap keterampilan membaca cepat siswa kelas V SD Gugus III Kintamani tahun ajaran 2017/2018. Desain penelitian ini adalah Penelitian Eksperimen semu dengan rancangan nonequivalent control group design. Populasi penelitian ini adalah seluruh siswa kelas V SD Gugus III Kintamani berjumlah 125 orang. Sampel dikumpulkan dengan teknik random sampling. Sampel dalam penelitian ini adalah siswa kelas V SDN Abuan dengan jumlah 33 siswa sebagai kelompok eksperimen dan siswa kelas V SDN Sekaan dengan jumlah 25 siswa sebagai kelompok kontrol. Pengumpulan data dilakukan dengan menggunakan metode tes essay. Data yang diperoleh dianalisis menggunakan uji-t. Hasil analisis data diperoleh $t_{\text {hitung }}=2,714$ sedangkan pada taraf signifikansi $5 \%$ dan $d k=56$ diperoleh nilai $t_{\text {tabel }}=2,000$ sehingga $t_{\text {hitung }}=$ $2,714>t_{\text {tabel }}=2,000$. Berdasarkan kriterian pengujian, maka Ho ditolak. Ini berarti terdapat perbedaan yang signifikan keterampilan membaca cepat antara kelompok eksperimen dan kelompok kontrol. Adapun nilai rata-rata keterampilan membaca cepat pada kelompok siswa yang dibelajarkan dengan model pembelajaran Directed Reading Thinking Activity (DRTA) adalah 81,31, sedangkan pada kelompok yang dibelajarkan dengan pembelajaran konvensional adalah 70,67. Berdasarkan hasil tersebut dapat disimpulkan bahwa terdapat pengaruh model pembelajaran Directed Reading Thinking Activity (DRTA) terhadap keterampilan membaca cepat siswa kelas V SD Gugus III Kintamani tahun ajaran 2017/2018.
\end{abstract}

Kata Kunci: Model Pembelajaran DRTA, Keterampilan Membaca Cepat.

\begin{abstract}
The purpose of this researched was to determine the effect of learning model Directed Reading Thinking Activity (DRTA) to the fast reading skill of students of grade V SD Kintamani III academic year of 2017/2018. The design of this researched is a quasi-experimental research with nonequivalent control group design. The population of this researched is all students of grade V SD Kintamani III that consist of 125 students. The sample were collected by random sampling technique. The sample in this researched is the students of grade V SDN Abuan that consist of 33 students as the experimental group and the students of grade V SDN Sekaan that consist of 25 students as the control group. The fast reading skill was collected by test essay. The data obtained were analyzed by using the t-test. The Result of data analysis obtained $t_{\text {count }}=2,714$ at $5 \%$ significance level and $\mathrm{dk}=56$, obtained $\mathrm{t}_{\text {table }}$ value $=2,000$ so $\mathrm{t}_{\text {count }}=2,714>\mathrm{t}_{\text {table }}=2,000$. Based on the test criteria, $\mathrm{H}_{\mathrm{o}}$ was rejected. This means that there is a significant difference in fast reading skill between the experimental group and the control group.The average score of fast reading skill in groups of students who are taught by Directed Reading Thinking Activity (DRTA) learning model is 81,31 , while in group which is taught by conventional learning is 70,67. Based on the result, it can be concluded that there is effect of learning model Directed Reading Thinking Activity (DRTA) to fast reading skill of class V SD Kintamani III academic year of 2017/2018.
\end{abstract}

Keywords: DRTA Learning, Fast Reading Skill

\section{Pendahuluan}

Pendidikan merupakan suatu usa-ha sadar yang terencana untuk mencipta-kan manusia yang berkompeten dan ber- kualitas. Pendidikan tersebut juga akan melahirkan peserta didik yang cerdas ser-ta mempunyai kompetensi dan skill untuk dikembangkan ditengah-tengah masyara-kat. Untuk mewujudkan hal ini tidak terle-pas dari faktor penentu dalam keberhasi-lan peserta didik dalam pendidikan.

Dalam penyelenggaraan pendidi-kan, proses pembelajaran dapat dikata-kan sebagai inti dari kegiatan pendidikan di sekolah. Menurut Undang-Undang Sis-tem Pendidikan Nasional No. 20 Tahun 2003, "pembelajaran adalah sebagai pro-ses interaksi peserta didik dengan pendi-dik dan sumber belajar pada suatu lingku-ngan belajar". Berdasarkan pendapat ter-sebut, dapat terlihat bahwa dalam proses pembelajaran terjadi interaksi antara pen-didik atau guru dengan peserta didik atau siswa dalam pencapaian tujuan belajar siswa itu sendiri. 
Tuntutan pembelajaran ditujukan kepada semua muatan materi salah satu muatan materi yang diajarkan adalah Ba-hasa Indonesia. Bahasa Indonesia mem-punyai peran penting dalam pengemba-ngan berbagai ilmu, dan memajukan daya pikir manusia. Pendidikan Bahasa Indone-sia secara resmi telah diajarkan dari seko-lah dasar sampai ke perguruan tinggi, pendidikan Bahasa Indonesia merupakan bagian yang tidak terpisahkan dari kuriku-lum pendidikan nasional. Membudayakan penggunaan Bahasa Indonesia yang baik dan benar sebaikanya dimulai dari sejak dini yaitu siswa SD dengan jalan mening-katkan kemampuan membaca cepat agar dapat memahami semua muatan dengan cepat, khususnya muatan materi Bahasa Indonesia.

Pembelajaran Bahasa Indonesia di SD diarahkan untuk mengembangkan kemampuan siswa untuk memahami dan menggunakan bahasa sebagai alat komu-nikasi secara efektif, baik secara lisan maupun tulis. Selain itu, pembelajaran Ba-hasa Indonesia di SD juga bertujuan untuk mengembangkan kemampuan bernalar, berkomunikasi, dan mengungkapkan piki-ran, perasaan serta membina persatuan dan kesatuan bangsa. Ruang lingkup ma-teri Bahasa Indonesia mencakup empat aspek keterampilan berbahasa, yakni ke-terampilan berbicara, keterampilan me-nyimak, keterampilan membaca, dan ke-terampilan menulis. Dalam pembelajaran bahasa Indonesia, keempat keterampilan berbahasa tersebut wajib dikuasai oleh siswa.

Selama ini siswa menganggap pembelajaran Bahasa Indonesia meru-pakan pembelajaran yang mudah, namun pada kenyataannya diperlukan keteram-pilan khusus dalam menguasai materi bahasa Indonesia khususnya pada kete-rampilan membaca. Dalman (2017:7) me-nyatakan bahwa "membaca adalah pro-ses perubahan bentuk /lambang /tanda/ tulisan menjadi wujud bunyi yang bermak-na". Dalam hal ini pembelajaran membaca harus memiliki keterampilan khusus se-hingga bisa memahami proses perubahan bentuk, lambang, tanda ataupun tulisan sehingga bisa menjadi bunyi yang ber-makna. Siswa dituntut untuk bisa mema-hami proses tersebut dan mengetahui makna yang ada dalam sebuah bacaan.

Keterampilan membaca dibeda-kan menjadi beberapa klasifikas, yaitu membaca pemahaman, membaca eks-tensif dan membaca cepat. Dalman (2017:74) menyatakan bahwa "membaca cepat (Speed Reading), ialah membaca dengan kecepatan tinggi, hanya memba-ca kalimat demi kalimat dan paragraf bu-kan per kata. Dalam hal ini kegiatan mem-baca dilakukan kalimat demi kalimat de-ngan kecepatan yang tinggi dan pemaha-man yang cukup.

Berdasarkan hasil observasi pada hari Jumat, 12 Januari 2018 dengan guru kelas V di SD Gugus III Kintamani, dite-mukan bahwa dalam pembelajaran baha-sa Indonesia 30\% dari 125 siswa yang be-lum mencapai hasil ketuntasan keteram-pilan membaca. Hal ini dapat dilihat dari kurangnya minat siswa dalam membaca sehingga proses pemahaman materi sa-ngat kurang serta proses pembelajaran menjadi pasif. Selain itu keterampilan membaca dianggap membosankan dan kurangnya penerapan model pembelaja-ran dalam proses pembelajaran, pada hal banyak hal yang menarik dalam keteram-pilan membaca yaitu dapat memperoleh informasi juga menyenangkan seperti hal-nya dalam membaca cerita, berita mau-pun buku pelajaran.

Untuk meningkatkan minat baca dan menjadikan proses pembelajaran yang aktif, maka diperlukan pemilihan mo-del pembelajaran yang tepat untuk kete-rampilan membaca. Pemilihan model pembelajaran sangat mempengaruhi ber-hasil atau tidaknya siswa dalam pembela-jaran membaca. Dalam pembelajaran Ba-hasa Indonesia terdapat model pembe-lajaran membaca yaitu Direct Reading Thinking Activity (DRTA) yang diharapkan mampu menjembatani permasalahan da-lam proses belajar membaca. Dalam pro-ses pembelajaran yang menggunakan model pembelajaran ini siswa dituntut me-nebak jalan cerita melalui gambar yang di-berikan oleh guru. Langkah ini merupakan cara guru untuk melatih metakognitif sis-wa yang berpikir sesuai dengan pikiran-nya sendiri tanpa dibatasi oleh guru. Tuju-an penggunaan model ini adalah untuk melatih siswa berkonsentrasi dan berpikir keras guna memahami isi bacaan secara serius. Model DRTA memfokuskan keterlibatan siswa dengan teks karena siswa memprediksi dan membuktikannya ketika mereka membaca.

Model Pembelajaran DRTA memi-liki beberapa kelebihan, yaitu: 1) memfo-kuskan keterlibatan siswa dengan teks, karena siswa memprediksi dan membukti-kannya ketika mereka membaca, 2) men-dorong siswa berfikir dengan jalan pikiran mereka sendiri, yaitu dengan membuat prediksi tentang apa yang akan terjadi dan apa yang tersirat dalam pesan teks, 3) model ini disertai dengan media pendu-kung, dalam hal ini media yang digunakan adalah media gambar, sehingga lebih membantu pemahaman siswa.

Berdasarkan uraian yang dipapar-kan tersebut, dapat dikatakan bahwa mo-del pembelajaran DRTA dapat mempe-ngaruhi keterampilan membaca cepat. Namun, seberapa jauh pengaruh model pembelajaran DRTA terhadap keterampi-lan membaca cepat siswa belum dapat di-ungkapkan. Untuk itu, peneliti hendak mengangkat masalah ini melalui suatu pe-nelitian yang berjudul "Pengaruh Model Pembelajaran Directed Reading Thinking Activity (DRTA) terhadap Keterampilan Membaca Cepat Siswa Kelas V SD Gu-gus III Kintamani Tahun Ajaran 2017/ 2018. 


\section{Metode}

Penelitian ini dilaksanakan pada kelas V SD Gugus III Kintamani tahun aja-ran 2017/2018. Pemilihan SD Gugus III Kintamani sebagai tempat penelitian kare-na keterjangkauan dan kelayakan. Keter-jangkauan dalam arti tempat penelitian mudah dijangkau oleh peneliti, serta kela-yakan dalam arti di SD Gugus III Kintama-ni belum pernah dilakukan penelitian yang sama dengan penelitian ini.

Jenis penelitian yang dilakukan dalam penelitian ini adalah penelitian ku-antitatif dengan desain eksperimental yaitu quasi experimental (Eksperimen Se-mu). "Quasi experimental design, digu-nakan karena pada kenyataannya sulit mendapatkan kelompok kontrol yang di-gunakan untuk penelitian". (Sugiyono, 2016:114). Bentuk desain yang digunakan dalam penelitian ini adalah "Nonequi-valent control group design". Pada desain ini kelompok eksperimen maupun kelom-pok kontrol tidak dipilih secara random. Dalam desain ini diberikan pretest untuk mengetahui keadaan awal adakah perbe-daan antara kelompok eksperimen dan kelompok kontrol.

Dalam penelitian ini melalui tahap-tahap pelaksanaan penelitian yang terdiri dari tiga tahapan yaitu, tahap persiapan, tahap pelaksanaan, dan tahap akhir pene-litian.

Berdasarkan hasil wawancara de-ngan ketua Gugus III Kintamani menyata-kan bahwa di Gugus III Kintamani tidak terdapat kelas unggulan. Pernyataan ter-sebut didukung oleh pendapat dari ma-sing-masing kepala sekolah yang berada di SD Gugus III Kintamani. Hal ini berarti semua kelas di SD Gugus III Kintamani di-nyatakan setara. Dikatakan setara, kare-na pengelompokan siswa kedalam kelas-kelas disebar secara merata antara siswa yang memiliki kemampuan tinggi, sedang maupun rendah.

Berdasarkan karakteristik populasi dan tidak bisa dilakukannya pengacakan individu, maka dalam penelitian ini, sam-pel dari populasi diambil dengan teknik random sampling. Menurut Sugiyono (2010:132) "random sampling adalah cara pengambilan sampel secara acak". Setiap kelas mendapatkan kesempatan yang sa-ma untuk dijadikan sampel.

Untuk menentukan sampel, cara yang digunakan adalah dengan cara pe-ngundian. Cara pengundian dilakukan de-ngan menulis semua nama kelas $\mathrm{V}$ di seluruh SD populasi pada masing-masing kertas yang jumlahnya 6 kelas, kemudian kertas digulung. Masukkan gulungan ker-tas ke dalam kotak dan dikocok, ambil dua gulungan kertas, Nama kelas dari masing-masing SD pada gulungan kertas tersebut merupakan sampel penelitian. setelah mendapatkan hasil undian, pretest diberi-kan untuk penyetaraan kelas, nilai atau skor dari hasil pretest dianalisis menggu-nakan uji t. Dan peneliti melakukan pe-ngundian lagi dari kedua sampel untuk memilih Kelas yang digunakan sebagai kelompok kontrol dan kelompok ekspe-rimen. Untuk mengetahui sampel benar-benar setara, dilakukan uji-t kesetaraan dengan rumus polled varians

Berdasarkan undian adapun sam-pel dalam penelitian ini yaitu SDN Abuan yang berjumlah 33 siswa muncul pertama dan dijadikan sebagai kelas eksperimen, sedangkan Kelas V SDN Sekaan yang berjumlah 25 siswa muncul pada undian kedua dan dijadikan sebagai kelas kon-trol. Pada kelas eksperimen diberikan perlakuan berupa model pembelajaran DRTA dan pada kelas kontrol dibelajarkan de-ngan pembelajaran konvensional.

Metode pengumpulan data yang digunakan pada penelitian ini adalah me-tode tes. Tes yang digunakan untuk me-ngukur keterampilan membaca cepat be-rupa tes essay. Jumlah butir soal disusun berdasarkan kisi-kisi tes keterampilan membaca sebanyak 15 butir soal yang ke-mudian diuji cobakan pada kelas yang jenjangnya lebih tinggi. Jumlah siswa yang terlibat uji coba instrumen dalam pe-nelitian ini yakni 26 orang dari siswa kelas VI SDN Abuan. Dari 15 butir soal yang te-lah diujikan maka diperoleh 10 butir soal yang dinyatakan layak untuk digunakan dalam peneitian ini.

Analisis data dalam penelitian ini meliputi analisis statistik deskriptif dan analisis statistik inferensial. Statistik des-kriptif merupakan statistik yang digunakan untuk menganalisis data dengan cara men-deskripsikan atau menggambarkan data yang telah terkumpul. "Statistik des-kriptif adalah cara pengolahan data yang dilakukan dengan jalan menerapkan ru-mus-rumus statistik deskriptif untuk meng-gambarkan suatu objek/variabel tertentu, sehingga diperoleh kesimpulan umum" (Agung, 2014:110).

Teknik analisis data deskriptif da-lam penelitian ini digunakan untuk menge-tahui penguasaan keterampilan membaca cepat siswa yang dibelajarakan dengan model pembelajaran DRTA dan keteram-pilan membaca cepat siswa yang dibela-jarkan dengan menggunakan model pem-belajaran konvensional. Pada statistik deskriptif ini data keterampilan membaca cepat siswa kelompok eksperimen dan kelompok kontrol disajikan untuk menge-tahui nilai rata-rata (mean), nilai dengan frekuensi tertinggi (modus), nilai tengah (median), standar deviasi, dan varians.

Analisis statistik inferensial meru-pakan statistik yang dipakai untuk melaku-kan analisis data dengan cara membuat kesimpulan yang berlaku secara umum. "Analisis statistik inferensial adalah cara pengolahan data yang dilakukan dengan jalan menerapkan rumus-rumus statistik inferensial untuk menguji suatu hipotesis penelitian yang diajukan peneliti dan ke-simpulan ditarik berdasarkan pengujian terhadap hipotesis" (Agung, 2014:110). Teknik analisis data yang dilakukan untuk menguji hipotesis dengan menggunakan uji-t. Sebelum dilakukan uji hipotesis ter-lebih dahulu dilakukan uji prasyarat anali-sis yang meliputi uji normalitas sebaran data dan homogenitas varians. 
Uji Normalitas dimaksudkan untuk mengetahui sebaran data skor Keteram-pilan membaca cepat siswa masing-ma-sing kelompok berdistribusi normal atau ti-dak. Uji Normalitas sebaran data dalam penelitian ini menggunakan uji Kolmogo-rov-smirnov. Kriteria pengujian adalah pada taraf signifikansinya adalah $5 \%$ dan derajat kebebasannya $\mathrm{n}-1$, jika $\mathrm{KS}_{\text {hitung }}<\mathrm{KS}_{\text {tabel }}$, maka $\mathrm{h}_{\mathrm{o}}$ diterima (gagal ditolak) yang berarti data berdistribusi normal.

Uji homogenitas varians dilakukan dengan uji F. Kriteria pengujian, pada taraf signifikan 5\% dengan

derajat kebe-basan untuk pembilang $\mathrm{n}_{1}-1$ dan derajat kebebasan untuk penyebut $\mathrm{n}_{2}-1$. Jika $F_{h i t}<F_{\text {tabel }}$ maka sampel homogen.

Data yang diperoleh sudah memenu-hi prasyarat uji normalitas dan homogeni-tas maka analisis yang digunakan adalah statistik parametrik. Analisis statistik yang digunakan untuk menguji hipotesis pene-litian ini adalah uji beda mean (uji t). Uji Hipotesis menggunakan uji-t dengan rumus polled varians. Rumus uji-t dengan rumus polled varians digunakan bila jumlah anggota sampel $\mathrm{n}_{1} \neq \mathrm{n}_{2}$ dan varians homogen. Dengan kriteria, pada

taraf signifikan 5\% dengan $\mathrm{dk}=\mathrm{n}_{1}+\mathrm{n}_{2}-2$, jika harga $\mathrm{t}_{\text {hitung }}<\mathrm{t}_{\text {tabel }}$, maka $\mathrm{H}_{\mathrm{o}}$ diterima, dan jika harga $\mathrm{t}_{\text {hitung }}>\mathrm{t}_{\text {tabel }}$ maka $\mathrm{H}_{\mathrm{o}}$ ditolak.

\section{Hasil dan Pembahasan}

Data hasil analisis statistik des-kriptif keterampilan membaca cepat kelompok eksperimen diperoleh dari 33 siswa terdapat nilai tertinggi 100 dan nilai terendah 50. Dari data tersebut diperoleh sebanyak 10 orang siswa mendapat nilai 100 , sebanyak 11 orang mendapat nilai 83,33 dan 10 orang mendapat nilai 66,67 serta 2 orang siswa mendapat nilai 50. Adapun rata-rata yang diperoleh dari data keterampilan membaca cepat tersebut adalah 81,31. Berikut ini data keterampi-lan membaca cepat siswa yang disajikan dalam Gambar 1 .

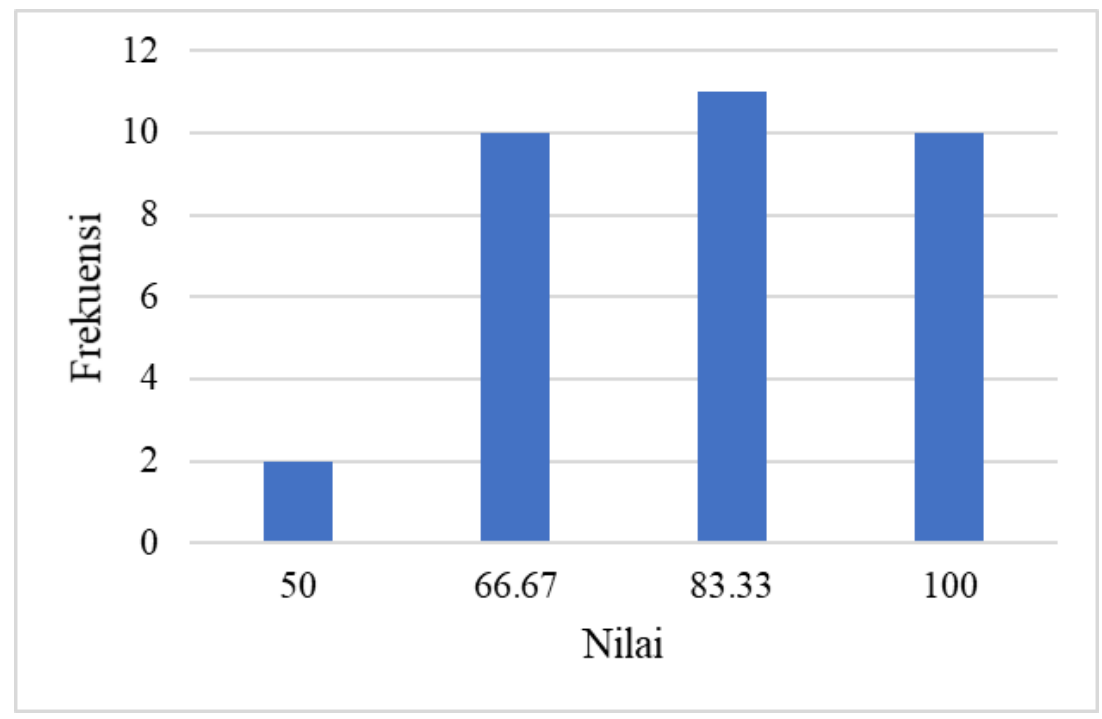

Gambar 1. Grafik Data Keterampilan Membaca Cepat Siswa Kelompok Eksperimen

Berdasarkan penyajian data kete-rampilan membaca cepat siswa kelompok eksperimen pada grafik batang yang ter-diri dari 33 siswa dengan nilai tertinggi yang diperoleh 100 dan nilai terendah adalah 50. Dari sebaran data tersebut diperoleh rata-rata (mean) adalah 81,31, nilai yang paling sering muncul adalah 83,33 dan nilai tengah (median) adalah 83,33. Data keterampilan membaca cepat kelompok eksperimen yang diperoleh varians adalah 238,81 dengan standar deviasi 15,45.

Data hasil analisis statistik des-kriptif keterampilan membaca cepat ke-lompok kontrol diperoleh dari 25 siswa ter-dapat nilai tertinggi 100 dan nilai terendah 50. Dari data tersebut diperoleh 1 orang siswa mendapat nilai 100 , sebanyak 9 orang mendapat nilai 83,33 dan 10 orang mendapat nilai 66,67 serta 5 orang siswa mendapat nilai 50. Adapun rata-rata yang diperoleh dari data keterampilan memba-ca cepat tersebut adalah 70,76. Berikut ini data keterampilan membaca cepat siswa yang disajikan dalam Gambar 2. 


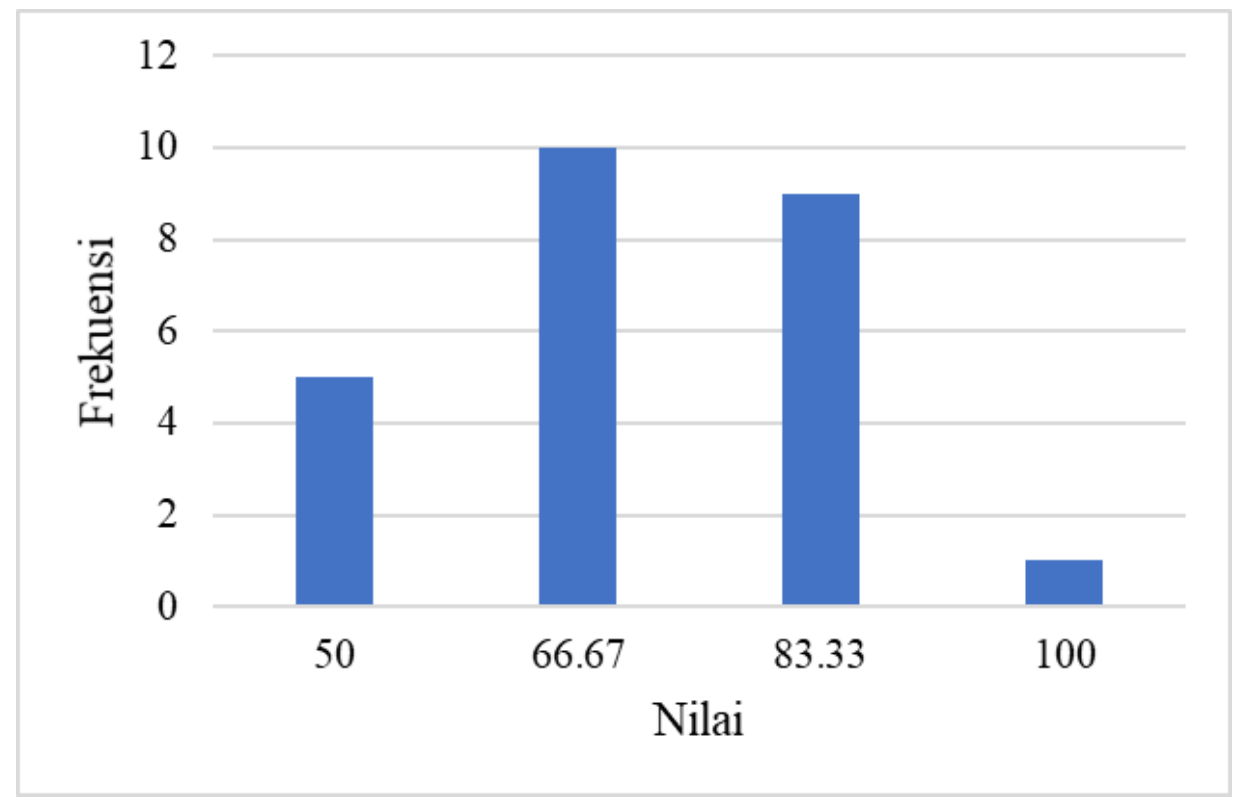

Gambar 2. Grafik Data Keterampilan

Berdasarkan penyajian data kete-rampilan membaca cepat siswa kelompok control grafik batang yang terdiri dari 25 siswa dengan nilai tertinggi yang dipero-leh 100 dan nilai terendah adalah 50. Dari sebaran data tersebut diperoleh rata-rata (mean) adalah 70,67, nilai yang paling sering muncul adalah 66,67 dan nilai tengah (median) adalah 66,67. Data keterampilan membaca cepat kelompok kontrol yang diperoleh varians adalah 191,62 dengan standar deviasi 13,84.

Sebelum dilaksanakan pengujian hipotesis terlebih dahulu dilakukan uji prasyarat analisis dengan uji normalitas dan uji homogenitas. Uji normalitas seba-ran data dimaksudkan untuk mengetahui sebaran data berdistribusi normal atau tidak. Berdasarkan perhitungan diperoleh $K S_{\text {hitung }}=0,192$ sedangkan untuk taraf signifikansi 5\% diperoleh $K S_{\text {tabel }}=0,202$. Karena $K S_{\text {hitung }}=0,192<K S_{\text {tabel }}=0,202$ maka $_{0}$ diterima sehingga data hasil keterampilan membaca cepat siswa kelas kelompok eksperimen berdistribusi nor-mal.

Berdasarkan perhitungan dipero-leh $K S_{\text {hitung }}=0,220$ sedangkan untuk taraf signifikansi $5 \%$ diperoleh $K S_{\text {tabel }}=0,264$. Karena $K S_{\text {hitung }}=0,220<K S_{\text {tabel }}=0,264$ maka $\mathrm{H}_{\mathrm{o}}$ diterima sehingga data hasil keterampilan membaca cepat siswa kelas kelompok control berdistribusi normal.

Pengujian homogenitas varians antar kelompok dimaksudkan untuk me-yakinkan bahwa perbedaan yang dipero-leh uji-t benar-benar berasal dari perbeda-an antar kelompok bukan disebabkan oleh perbedaan di dalam kelompok. Dari hasil analisis data diketahui varians kelompok eksperimen adalah 238,81 dan varians kelompok kontrol adalah 191,62. Dari hasil perhitungan diperoleh $F_{\text {hitung }}=1,25$, harga ini kemudian dibandingkan dengan harga $F_{\text {tabel }}$ dengan derajat kebebasan pembilang $=33-1=32$ dan derajat kebebasan penyebut $=25-1=24$ dengan taraf signifikansi $5 \%$, sehingga diperoleh $F_{\text {tabel }}=1,94$. Karena harga $F_{\text {hitung }}<F_{\text {tabel }}$ $(1,25<1,94)$. Ini berarti varians data keterampilan membaca cepat antara kelompok eksprimen dan kelompok kon-trol adalah sama atau homogen.

Berdasarkan hasil perhitungan uji normalitas data dan uji homogenitas dike-tahui bahwa data yang diperoleh berdistri-busi normal dan memiliki varians yang homogen, maka selanjutnya uji hipotesis dapat

digunakan rumus uji-t. Dari hasil uji-t diperoleh $t_{\text {hitung }}=2,714$ sedangkan nilai $t_{\text {tabel }}$ pada taraf signifikansi $5 \%$ dengan derajat kebebasan $(\mathrm{dk}=25+33-2=56)$ adalah 2,000 . Karena $t_{\text {hitung }}>\mathrm{t}_{\text {tabel }}(2,714>2,000)$ maka

$H_{\text {o }}$ yang berbunyi tidak terdapat perbedaan yang signifikan keterampilan membaca cepat antara ke-lompok siswa yang dibelajarkan dengan model pembelajaran DRTA dengan ke-lompok siswa yang dibelajarkan dengan model pembelajaran konvensional pada siswa kelas V SD Gugus III Kintamani Tahun Ajaran 2017/2018 ditolak

dan $H_{a}$ yang berbunyi terdapat perbedaan yang signifikan keterampilan membaca cepat antara kelompok siswa yang dibelajarkan dengan model pembelajaran DRTA deng-an kelompok siswa yang dibelajarkan dengan model pembelajaran konvensio-nal pada siswa kelas V SD Gugus III Kintamani Tahun Ajaran 2017/2018 diterima. 
Berdasarkan hasil penelitian yang diperoleh bahwa terdapat perbedaan yang signifikan keterampilan membaca cepat antara kelompok siswa yang dibela-jarkan dengan model pembelajaran DRTA dengan kelompok siswa yang dibelajar-kan dengan model pembelajaran konven-sional pada siswa kelas V SD Gugus III

Kintamani Tahun Ajaran 2017/2018. Hal ini dibuktikan dengan hasil uji-t yang diperoleh dengan $t_{\text {hitung }}=$ 2,714 sedang-kan nilai $t_{\text {tabel }}$ pada taraf signifikansi $5 \%$ dengan derajat kebebasan $(\mathrm{dk}=25+33-2=56)$ adalah 2,000 sehingga $t_{\text {hitung }}>t_{\text {tabel }}(2,714>2,000)$.

Perolehan hasil perhitungan analisis data yang dilakukan dengan menunjukkan nilai rata-rata siswa yang mengikuti pembelajaran menggunakan model pembelajaran DRTA $(\bar{X}=81,31)$ dan siswa yang mengikuti pembelajaran konvensional ( $\bar{X}=70,67)$ memiliki perbedaan sebesar 10,64. Berdasarkan hasil temuan tersebut, setelah kedua kelompok dinyatakan setara dan diberikan perlakuan berupa pembelajaran dengan model pembelajaran DRTA pada kelom-pok eksperimen dan pembelajaran kon-vensional pada kelompok kontrol, dipero-leh hasil keterampilan membaca cepat yang berbeda. Hal ini dapat dilihat dari rata-rata nilai siswa yang mengikuti pembelajaran dengan model pembelaja-ran DRTA lebih tinggi dibandingkan dengan rata-rata nilai siswa yang mengi-kuti pembelajaran konvensional. Perbe-daan hasil keterampilan membaca cepat tersebut disebabkan oleh perlakuan berupa model pembelajaran DRTA pada kelompok eksperimen.

Dalam proses pembelajaran yang menggunakan model pembelajaran DRTA siswa dituntut menebak jalan cerita melalui gambar yang diberikan oleh guru. Langkah ini merupakan cara guru untuk melatih metakognitif siswa yang berpikir sesuai dengan pikirannya sendiri tanpa dibatasi oleh guru. Tujuan penggunaan model ini adalah untuk melatih siswa berkonsentrasi dan berpikir keras guna memahami isi bacaan secara serius. Model DRTA memfokuskan keterlibatan siswa dengan teks karena siswa memprediksi dan membuktikannya ketika mereka membaca. Model pembelajaran ini menuntut siswa dalam menanyakan beberapa pertanyaan tentang teks yang mereka baca, membuat prediksi tentang garis besar cerita dalam teks, dan kemudian membaca untuk mengkonfir-masi atau membantah prediksi mereka sebelumnya tentang isi bacaan. Dalam pembelajaran dengan model pembela-jaran DRTA, siswa dapat membaca dengan cepat dan memahami isi bacaaan dengan jelas dan cepat, sehingga siswa akan mampu menjawab prediksi yang dibuat dengan membaca cepat.

Dalam memprediksi bacaan dan mengkonfirmasi hasil prediksi, siswa akan bekerjasama dengan kelompok. Siswa diberikan kesempatan untuk mengung-kapkan pendapat tentang prediksi yang telah dibuat dengan hasil dari prediksi tentang isi bacaan tersebut. Dalam pembelajaran ini, guru berperan sebagai fasilitator sehingga proses pembelajaran yang dilakukan berpusat pada siswa. Hal tersebut sejalan dengan pendapat Stauffer (2008) yang menjelaskan bahwa guru bisa memotivasi usaha dan konsentrasi siswa dengan melibatkan mereka secara intelektual serta mendo-rong mereka merumuskan hipotesis, memproses informasi, dan mengevaluasi sementara. Dalam proses pembelajaran, siswa diajak untuk menebak jalan cerita sehingga siswa akan tertarik untuk mem-baca teks bacaan. Dalam pembelajaran model DRTA memiliki peranan yang besar untuk melatih konsentrasi siswa. Hal tersebut akan membentuk metakognitif siswa sehingga bisa memahami isi baca-an dengan cepat dan tepat.

Hasil penelitian ini memperkuat simpulan yang disampaikan oleh Wiguna (2014) menyatakan, model pembelajaran DRTA berpengaruh terhadap hasil belajar membaca intensif siswa kelas IV semes-ter I di SD Gugus Belantih Kecamatan Kintamani Kabupaten Bangli. Dengan demikian, dapat dikatakan bahwa model pembelajaran Directed Reading Thinking Activity (DRTA) berpengaruh terhadap keterampilan membaca cepat siswa kelas V SD Gugus III Kintamani Tahun Ajaran 2017/2018.

\section{Simpulan}

Berdasarkan hasil penelitian, da-pat disimpulkan yaitu hasil analisis data keterampilan membaca cepat pada ke-lompok eksperimen terdapat 33 orang siswa dengan nilai tertinggi 100 dan nilai terendah 50. Dari sebaran data tersebut diperoleh rata-rata (mean) sebesar 81,31 , dan yang data yang paling sering muncul (modus) adalah 83,33, dan nilai tengah (median) adalah 83,33. Rata-rata nilai keterampilan membaca cepat dikonversikan pada PAP dapat dikategorikan baik. Hasil analisis data keterampilan membaca cepat pada kelompok kontrol terdapat 25 orang siswa dengan nilai tertinggi 100 dan nilai terendah 50. Dari sebaran data terse-but diperoleh rata-rata (mean) sebesar 70,67, dan yang data yang paling sering muncul (modus) adalah 66,67, dan nilai tengah (median) adalah 66,67. Rata-rata nilai keterampilan membaca cepat dikon-versikan pada PAP dapat dikategorikan cukup. Berdasarkan hasil analisis data keterampilan membaca cepat dengan uji-t diperoleh

$t_{\text {hitung }}=2,714$ sedangkan nilai $t_{\text {tabel }}$ pada taraf signifikansi $5 \%$ dengan derajat kebebasan $(\mathrm{dk}=25+33-2=$

56) adalah 2,000. Karena $\mathrm{t}_{\text {hitung }}>\mathrm{t}_{\text {tabel }}(2,714>2,000)$ maka $H_{o}$ yang berbunyi tidak ter-dapat perbedaan yang signifikan keteram-pilan membaca cepat antara kelompok siswa yang dibelajarkan dengan model pembelajaran DRTA dengan kelompok siswa yang dibelajarkan dengan model pembelajaran konvensional pada siswa kelas V 
SD Gugus III Kintamani tahun ajaran 2017/2018 ditolak dan $H_{a}$ yang berbunyi terdapat perbedaan yang signify-kan keterampilan membaca cepat antara kelompok siswa yang dibelajarkan dengan model pembelajaran DRTA dengan kelompok siswa yang dibelajar-kan dengan model pembelajaran konven-sional pada siswa kelas V SD Gugus III Kintamani tahun ajaran 2017/2018 diteri-ma. Dari sebaran data tersebut diperoleh rata-rata (mean) sebesar 81,31, dan yang data yang paling sering muncul (modus) adalah 83,33, dan nilai tengah (median) adalah 83,33. Rata-rata nilai keterampilan membaca cepat dikonversikan pada PAP dapat dikategorikan baik. Jadi dapat disimpulkan bahwa model pembelajaran DRTA berpengaruh tehadap keterampilan membaca cepat siswa kelas V SD Gugus III Kintamani tahun ajaran 2017/2018.

Berdasarkan hasil penelitian, pembahasan dan simpulan, maka dapat diajukan beberapa saran kepada bebe-rapa pihak sebagai berikut. 1) Kepada Guru, berdasarkan temuan penelitian yang diperoleh, disarankan kepada guru agar lebih kreatif untuk memberikan vari-asi dalam pembelajaran. fasilitas berupa sumber belajar dan kesempatan yang lebih besar bagi siswa pada pembelajaran dengan menggunakan model pembelaja-ran DRTA lingkungan sehingga tercipta pembelajaran bermakna dan menyenang-kan bagi siswa.2) Kepada Kepala Seko-lah, berdasarkan temuan penelitian, disa-rankan kepada kepala sekolah agar dapat menggunakan hasil penelitian ini sebagai pendukung sumber belajar guru dalam meningkatkan kualitas pembelajaran dengan menciptakan variasi pembelaja-ran yang menyenangkan di sekolah sehingga sekolah mampu menghasilkan siswa yang berkualitas. 3) Kepada peneliti lain, berdasarkan temuan penelitian, di-sarankan kepada peneliti agar hasil penelitian ini digunakan sebagai referensi untuk melaksanakan penelitian selanjut-nya atau menemukan inovasi kegiatan pembelajaran lainnya yang bermakna dan menyenangkan bagi siswa.

\section{Daftar Pustaka}

Agung, A.A. Gede. 2014. Metodologi Penelitian Pendidikan. Malang: Aditya Media Publishing. Agung, A.A. Gede. 2016. Statistika Dasar Untuk Pendidikan. Yogyakarta: Deepublish. Arikunto, Suharsimi. 2016. Dasar-dasar Evaluasi Pendidikan. Jakarta: Bumi Aksara Dalman, Dr. H. 2017. Keterampilan Membaca. Jakarta: PT. Raja Grafindo Persada.

Kusuma, Ida Bagus Indra. 2014. "Pengaruh Strategi Direct Reading Thinking Activty (DRTA) terhadap Keterampilan Membaca Pemahaman Siswa" Mimbar PGSD, Vol. 2 No. 1 (hlm. 1-10).

Mairing, Jackson Pasini. 2017. Statistika Pendidikan. Yogyakarta: CV. Andi Offest.

Rahim, Farida. (2008). Pengajaran Membaca Di Sekolah Dasar. Jakarta: PT. Bumi Angsara.

Setyosari, H. Punaji. 2015. Metode Penelitian Pendidikan \& Pengembangan. Jakarta: Prenamedia Group.

Sugiyono. 2010. Statistik Untuk Penelitian. Bandung: Alfabeta.

Tarigan, H. (2008). Membaca Sebagai Suatu Keterampilan Berbahasa. Bandung: Penerbit Angkasa.

Undang-Undang No. 20 Tahun 2003 tentang Sistem Pendidikan Nasional. Jakarta: Depdiknas.

Wiguna, I Wyn. Radiarta. 2014. "Pengaruh Strategi DRTA (Directed Reading Thinking Activity) Terhadap Hasil Belajar Membaca Intensif Siswa Kelas IV Semester 1 SDN Gugus Belantih Kecamatan Kintamani Tahun Pelajaran 2013 /2014” Mimbar PGSD, Vol. 2 No. 1 (hlm. 1-10). 